\title{
The Unwelcome Albino
}

\author{
By ARTHUR WARD, Swift Current
}

Often associations closely linked in a pattern cf an accepted standard elicits the expression, "Birds of a feather flock together". Even in the matter of plumage aberration we see that the tendency of the main flock is to resist the inclusion of the albino. It is more often seen behind on in the outer fringe in flight. In the case of an albino sparrow we saw that there was a marked contrast as it flew from a lilac hedge following a small flock of English Sparrows across the street.

The fleeting glance suggested a bird of some other species, until later it was seen flying along behind the others. A slightly mottled feather left behind was one which showed a makeup as lacking in natural colouring matter of the usual plumage. We had hoped to retain this novelty in our district as something of an unusual sight. Even with the faintly mottled feathering in pale ivory this was a fine example of an albino, and was very conspicuous when seen flying with other sparrows which, we fear, tended to its final disappearance.

We had expected a much larger number of those birds that sometimes stay over winter, but noticed a decrease in this area. About twelve Bohemian Waxwings, one Downy Woodpecker and eight Starlings were observed here. A Meadowlark was reported to have been seen at Shackleton during the third week in January. We saw one male Ringneck Pheasant with the females feeding across the street amongst the shrubbery of a vacant lot. Feed had been placed there for them. It was a fine sight to look out of the window and see them feeding there almost every day. These, we understand, had been raised locally and released. If not molested they may rest along the creek side where there is sufficient color and food.

\section{Nature 1904 - 1955}

\author{
By Mrs. T. H. BRAY, McLean \\ and \\ Mrs. HILDA NEW'TON, Indian Head
}

The year 1904! A stretch of green prairie, two hills (the settlers' landmark) beside a newly built frame house, fragrant with the smell of pine from the new lumber. Another pioneer, full of hope, was bringing his family home.

The fall before had seen widespread prairie fires; possibly started by trains, travelling relentlessly for miles. They presented a terrifying sight to the settlers, especially at night, resembling a necklace as they swept over the distant hills. The prairie, thus cleansed of its dead grass the fall before, now resembled a vast green lawn, dotted with purple crocuses, later with clusters of blue violets. As the summer advanced the everchanging panorama of colour delighted the eyes of the younger pioneers.

In our many joyous ramblings we came upon many species of wild flowers that are seldom. seen today, such as fringed and bottled gentian dusty pink primroses and shooting star and spicy senaca-root - much sought by the Indians. But outstanding in our memory were the flaming patches of red lillies, encircling the alkaline marshlands . in hundreds. (These will also thrive in your garden if given an undisturbed spot). Lady Slippers, too, were plentiful; many having three flowers. These are very scarce today.

To satisfy young appetites were the piquent wild strawberries, found in profusion along with other native berries, such as June-berry, Saskatoons, etc. How we all enjoyed them! They were the only fresh fruit obtainable by the early settlers until fall, when Ontario apples came along in time to fill the threshers' favourite pies.

(Continued on Page 21) 